\title{
Article \\ Oxidative Stress at Birth Is Associated with the Concentration of Iron and Copper in Maternal Serum
}

\author{
Karolina Rak $^{1, *}$, Karolina Łoźna ${ }^{1} \mathbb{D}$, Marzena Styczyńska ${ }^{1}$, Lukasz Bobak $^{2} \mathbb{D}$ and Monika Bronkowska ${ }^{1} \mathbb{D}$ \\ 1 Department of Human Nutrition, Faculty of Biotechnology and Food Science, Wrocław University of \\ Environmental and Life Sciences, 51-630 Wrocław, Poland; karolina.lozna@upwr.edu.pl (K.Ł.); \\ marzena.styczynska@upwr.edu.pl (M.S.); monika.bronkowska@upwr.edu.pl (M.B.) \\ 2 Department of Functional Food Products Development, Faculty of Biotechnology and Food Science, \\ Wrocław University of Environmental and Life Sciences, 51-630 Wrocław, Poland; lukasz.bobak@upwr.edu.pl \\ * Correspondence: karolina.rak@upwr.edu.pl
}

Citation: Rak, K.; Łoźna, K.; Styczyńska, M.; Bobak, Ł.; Bronkowska, M. Oxidative Stress at Birth Is Associated with the Concentration of Iron and Copper in Maternal Serum. Nutrients 2021, 13, 1491. https://doi.org/10.3390/ nu13051491

Academic Editor: Bruce W. Hollis

Received: 8 April 2021

Accepted: 25 April 2021

Published: 28 April 2021

Publisher's Note: MDPI stays neutral with regard to jurisdictional claims in published maps and institutional affiliations.

Copyright: (c) 2021 by the authors. Licensee MDPI, Basel, Switzerland. This article is an open access article distributed under the terms and conditions of the Creative Commons Attribution (CC BY) license (https:// creativecommons.org/licenses/by/ $4.0 /)$.

\begin{abstract}
Oxidative stress (OS) in the foetal and neonatal periods leads to many disorders in newborns and in later life. The nutritional status of pregnant women is considered to be one of the key factors that triggers OS. We investigated the relationship between the concentration of selected mineral elements in the blood of pregnant women and the concentration of $3^{\prime}$ nitrotyrosine $\left(3^{\prime} \mathrm{NT}\right)$ as a marker of OS in the umbilical cord blood of newborns. The study group consisted of 57 pregnant women and their newborn children. The concentrations of magnesium (Mg), calcium (Ca), iron (Fe), zinc $(\mathrm{Zn})$ and copper $(\mathrm{Cu})$ in maternal serum (MS) were measured by the flame atomic absorption/emission spectrometry (FAAS/FAES) method. The concentration of $3^{\prime} \mathrm{NT}$ in umbilical cord serum (UCS) of newborns was determined by the ELISA method. A positive correlation between MS Fe and UCS $3^{\prime} \mathrm{NT}$ in male newborns was shown (rho $=0.392, p=0.053$ ). Significantly higher UCS $3^{\prime}$ NT was demonstrated in newborns, especially males, whose mothers were characterized by MS Fe higher than $400 \mu \mathrm{g} / \mathrm{dL}$ compared to those of mothers with MS Fe up to $300 \mu \mathrm{g} / \mathrm{dL}(p<0.01)$. Moreover, a negative correlation between the MS Cu and UCS $3^{\prime} \mathrm{NT}$ in male newborns was observed (rho $=-0.509, p=0.008$ ). Results of the study showed the need to develop strategies to optimize the nutritional status of pregnant women. Implementation of these strategies could contribute to reducing the risk of pre- and neonatal OS and its adverse health effects in the offspring.
\end{abstract}

Keywords: oxidative stress; 3'nitrotyrosine; nutritional status; mineral elements; pregnant women

\section{Introduction}

Oxidative stress (OS) is a state of disturbed balance between oxidation and reduction processes. There is an overproduction of reactive oxygen and nitrogen species (ROS/RNS), which causes structural changes and damage to lipid molecules, nucleic acids and proteins, resulting in modification of their biological functions or complete deactivation [1-5].

OS is especially unfavourable in the pre- and neonatal period, when intensively multiplying cells and developing tissues of young organisms are particularly sensitive to the harmful effects of ROS/RNS produced under the influence of various factors [6-13]. OS in early life may result in the development of "oxygen radical disease in neonatology" [14-20] as well as foetal programming [6,21,22], that determines susceptibility to cardiometabolic [6,21,23-26] and immunological diseases in later life [7,27-32]. Figure 1 shows the triggers of OS in the pre- and neonatal period and its health consequences in newborns and later in life.

During foetal life, many factors can induce OS in the foetus-(1) teratogens (e.g., chemicals, pathogenic microorganisms, drugs, alcohol and tobacco), (2) disturbed hormonal environment (resulting from maternal obesity, excessive weight gain in pregnancy, diabetes and stress), (3) complications in the course of pregnancy (including pre-eclampsia, gestational hypoxia and placental insufficiency), and (4) inflammation (resulting from infection) [6-9]. 


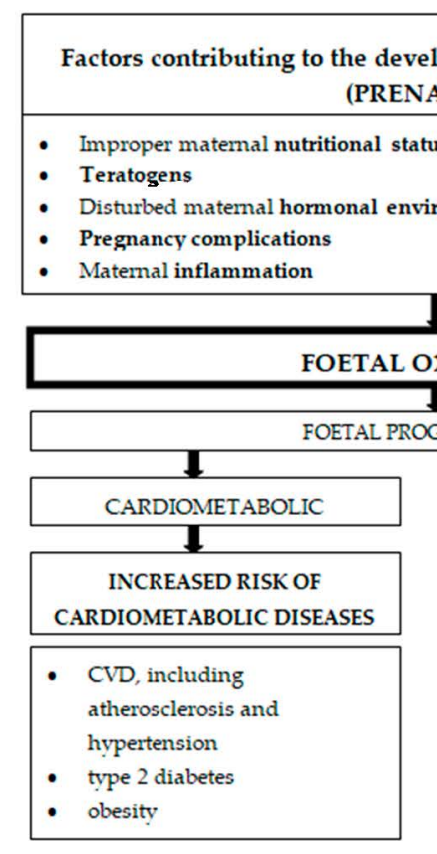

development of oxid

Factors contributing to the development of oxidative stress in newborns (NEONATAL PERIOD)

- Labour - passing from hypoxic to normoxic environment

- Infections - immature immune system

- Free iron - production of hydroxyl radicals

- Not fully functional antioxidant mechanisms

XIDATIVE STRESS

I

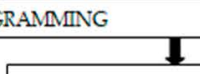

OF IMMUNE SYSTEM

INCREASED RISK OF IMMUNE-RELATED DISEASES

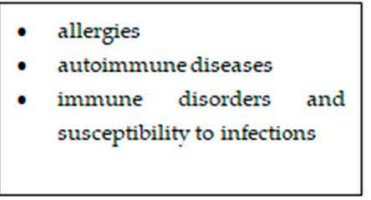

OXYGEN RADICAL DISEASE IN NEONATOLOGY

NEONATAL OXIDATIVE STRESS
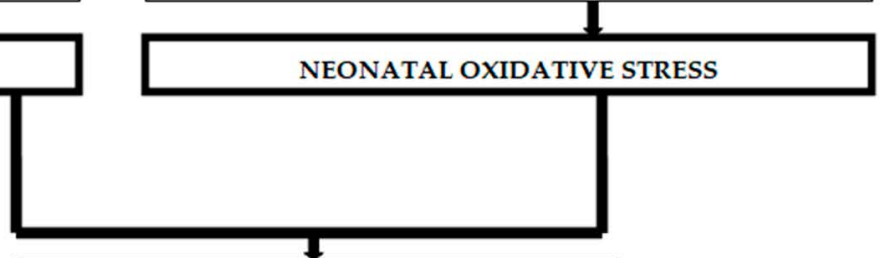

\begin{tabular}{|c|c|}
\hline $\begin{array}{ll}\text { - } & \text { BPD } \\
\text { - } & \text { PEC } \\
\text { - } & \text { IVH } \\
\text { - } & \text { PVL }\end{array}$ & $\begin{array}{ll}\text { - } & \text { RDS } \\
\text { - } & \text { ROP } \\
\text { - } & \text { IUGR } \\
\text { - } & \text { congenital } \\
\text { malformations }\end{array}$ \\
\hline
\end{tabular}

Figure 1. The impact of pre- and neonatal oxidative stress on the health of newborns and health predispositions in later life. CVD—cardiovascular disease; BPD—bronchopulmonary dysplasia; NEC—necrotizing enterocolitis; PDA—patent ductus arteriosus; IVH—intraventricular haemorrhage; PVL—periventricular leukomalacia; RDS—respiratory distress syndrome; ROP—retinopathy of prematurity; IUGR—intrauterine growth restriction.

The improper nutritional status (insufficient, excessive or unbalanced) of pregnant women has also been demonstrated to be one of the key maternal pro-oxidative factors that triggers, by activating the hypothalamic-pituitary-adrenal (HPA) axis [27], a stressful intrauterine environment and can lead to foetal and neonatal OS [6-9]. Increased demand for nutrients during pregnancy very often results in their deficiency [33-38]. On the other hand, the use of dietary supplements by pregnant women may contribute to the excessive supply of nutrients, especially vitamins and mineral elements $[39,40]$. Inappropriate proportions of nutrients in the diet, especially in the Western model of nutrition, may also result in disturbance of nutritional status of pregnant women [41].

Mineral elements play many important biological roles in the human organism [42,43], including in the redox balance. Iron $(\mathrm{Fe})$, copper $(\mathrm{Cu})$ and zinc $(\mathrm{Zn})$ - trace elements from the group of transition metals - are able to adopt various oxidation states by accepting or donating electrons from the outer shell. Therefore, they can act as pro- and antioxidants and their concentration in the body is strictly regulated [44-46]. As both insufficiency and excess of $\mathrm{Fe}, \mathrm{Cu}$ and $\mathrm{Zn}$ have been demonstrated to cause OS, the relationship between the concentration of these mineral elements in the body and the level of OS is defined as U-shaped [47-50].

In physiological conditions, Fe is involved in the production of ROS/RNS as an antimicrobial defence mechanism [51], while Fe overload is considered one of the major pro-oxidative factors by driving the Fenton reaction and the production of highly reactive hydroxyl radicals [49]. In turn, $\mathrm{Cu}$ and $\mathrm{Zn}$ play a role in antioxidant processes as components of copper-zinc superoxide dismutase (Cu-Zn SOD) which is one of the key elements of intracellular antioxidant mechanisms [44,50]. Insufficient levels of $\mathrm{Cu}$ and $\mathrm{Zn}$ may promote OS by impairing antioxidant mechanisms [44,50,52,53].

Magnesium (Mg) has been demonstrated to influence the level of OS in the organism [54] and its insufficiency (hypomagnesaemia) can promote ROS/RNS production [55]. In turn, calcium $(\mathrm{Ca})$ is essential for the proper course of many stages of the reproductive process, including the development of the placenta [56] —a key structure ensuring intrauterine homeostasis and buffering the influence of adverse stimuli on the developing foetus. 
Although in the literature there are presented results suggesting that both insufficiency and excess of mineral elements in pregnancy may have adverse effects for foetal development, maternal health and health of their offspring [33,57], according to our best knowledge, there are no studies that examined the relationship between status of mineral nutrition in pregnancy and the level of OS in newborns.

We therefore aimed to investigate the relationship between the concentration of mineral elements $(\mathrm{Ca}, \mathrm{Mg}, \mathrm{Fe}, \mathrm{Cu}, \mathrm{Zn})$ in the blood of pregnant women and the concentration of $3^{\prime}$ nitrotyrosine $\left(3^{\prime} \mathrm{NT}\right)$ as an OS marker in the umbilical cord blood of newborns. We hypothesized that an insufficient or an excessive concentration of examined mineral elements in maternal serum may increase the level of OS in their newborn children.

\section{Materials and Methods}

\subsection{Patients}

A total of 57 full-term healthy neonates (31 females and 26 males) born in the Obstetrics and Gynaecology Ward of Provincial Specialist Hospital in Wroclaw Research and Development Centre (Poland) between April 2016 and December 2016 and their mothers were enrolled in the study. All examined women declared no alcohol and tobacco use throughout the pregnancy and had uncomplicated pregnancies terminated with caesarean section (no labour) due to obstetric (previous caesarean section), ophthalmological (advanced eye defect) or psychiatric (tokophobia) indications. Women with natural labour were not enrolled in the study. Characteristics of mothers and newborns are presented in Table 1, taking into account the data on maternal age, pre-pregnancy BMI, gestational weight gain, concentrations of selected mineral elements in the MS, gestational age of newborns, their birth weight and concentration of $3^{\prime} \mathrm{NT}$ in the UCS. Moreover, the frequency of insufficient, optimal and excessive concentrations of selected mineral elements in the blood serum of pregnant women in relation to the reference values for pregnant women in the 3rd trimester [58] are presented in Table 2.

Table 1. Characteristics of mothers and newborns $(\mathrm{N}=57)$.

\begin{tabular}{|c|c|c|c|c|c|}
\hline & Mean & SD & Median & IQR & Range \\
\hline \multicolumn{6}{|l|}{ Maternal characteristics } \\
\hline Maternal age [years] & 33.01 & 4.90 & 33.00 & $30.00-35.00$ & $19.00-50.00$ \\
\hline Pre-pregnancy BMI $\left[\mathrm{kg} / \mathrm{m}^{2}\right]$ & 23.21 & 4.24 & 22.09 & 20.19-25.24 & $16.73-40.12$ \\
\hline Gestational weight gain $[\mathrm{kg}]$ & 14.88 & 4.62 & 14.00 & $12.00-18.00$ & $5.00-25.50$ \\
\hline MS Mg $[\mathrm{mg} / \mathrm{dL}]$ & 1.24 & 0.14 & 1.22 & $1.15-1.33$ & $0.93-1.66$ \\
\hline MS Ca [mg/dL] & 17.33 & 3.21 & 17.61 & $15.93-18.77$ & $8.34-26.94$ \\
\hline MS Fe $[\mu \mathrm{g} / \mathrm{dL}]$ & 382.0 & 264.7 & 328.5 & $169.0-555.0$ & $0.01-1603.0$ \\
\hline MS Cu [ $\mu \mathrm{g} / \mathrm{dL}]$ & 83.31 & 56.0 & 78.02 & $44.00-123.2$ & $0.00-248.1$ \\
\hline MS Zn $[\mu \mathrm{g} / \mathrm{dL}]$ & 19.36 & 16.16 & 17.65 & $0.00-32.80$ & $0.00-56.30$ \\
\hline \multicolumn{6}{|l|}{ Neonatal characteristics } \\
\hline Gestational age [weeks] & 38.78 & 0.88 & 39.00 & $38.00-39.00$ & $37.00-41.00$ \\
\hline \& & 38.89 & 0.96 & 39.00 & $38.00-39.00$ & $37.00-41.00$ \\
\hline क & 38.65 & 0.78 & 39.00 & $38.00-39.00$ & $37.00-41.00$ \\
\hline Birth weight $[\mathrm{g}]$ & 3466.9 & 447.7 & 3405.0 & $3150.0-3710.0$ & $2490.0-4980.0$ \\
\hline \& & 3446.3 & 424.4 & 3380.0 & $3140.0-3680.0$ & $2580.0-4980.0$ \\
\hline क & 3490.0 & 476.6 & 3460.0 & $3170.0-3730.0$ & $2490.0-4660.0$ \\
\hline UCS $3^{\prime} \mathrm{NT}[\mathrm{pg} / \mathrm{mL}]$ & 255.7 & 74.13 & 244.1 & 214.6-272.4 & $142.6-582.9$ \\
\hline 8 & 256.9 & 81.67 & 245.7 & $215.2-261.8$ & $154.0-582.9$ \\
\hline क & 254.1 & 64.33 & 236.8 & 210.33-297.5 & $142.5-384.2$ \\
\hline
\end{tabular}

MS—maternal serum, UCS—umbilical cord serum, $3^{\prime} \mathrm{NT}-3^{\prime}$ nitrotyrosine, $8 \mathrm{q} \mathrm{N}=31, \odot^{\mathrm{O}} \mathrm{N}=26$, IQR—interquartile range. 
Table 2. The frequency of insufficient, optimal and excessive concentrations of selected mineral elements in the blood serum of pregnant women in relation to the reference values for pregnant women in the 3rd trimester *.

\begin{tabular}{ccccc}
\hline Mineral Elements & Reference Values $^{*}$ & Insufficient [\%] $^{\mathbf{1}}$ & Optimal [\%] $^{\mathbf{2}}$ & Excessive [\%] $^{\mathbf{3}}$ \\
\hline $\mathrm{Mg}[\mathrm{mg} / \mathrm{dL}]$ & $1.1-2.2$ & 15.8 & 84.2 & - \\
$\mathrm{Ca}[\mathrm{mg} / \mathrm{dL}]$ & $8.2-9.7$ & - & - & 100 \\
$\mathrm{Zn}[\mu \mathrm{g} / \mathrm{dL}]$ & $50-77$ & 96.5 & 3.5 & - \\
$\mathrm{Fe}[\mu \mathrm{g} / \mathrm{dL}]$ & $30-193$ & 1.8 & 38.6 & 59.6 \\
$\mathrm{Cu}[\mu \mathrm{g} / \mathrm{dL}]$ & $130-240$ & 66.7 & 31.5 & 1.8 \\
\hline
\end{tabular}

${ }^{*}$ Ref. [58], ${ }^{1}$ Insufficient-below the lower limit of the reference values, ${ }^{2}$ Optimal—within the reference values, ${ }^{3}$ Excessive-above the upper limit of the reference values.

\subsection{Determination of Concentration of Mineral Elements in Maternal Serum}

Maternal blood samples were collected before planned caesarean section (no labour). Blood samples after clotting were centrifuged for $15 \mathrm{~min}$ at $2000 \mathrm{rpm}$. Serum samples were removed and stored at $-80^{\circ} \mathrm{C}$ until the analysis [59]. The concentrations of $\mathrm{Ca}, \mathrm{Mg}, \mathrm{Zn}, \mathrm{Fe}$ and $\mathrm{Cu}$ in maternal serum (MS) were measured by means of flame absorption (emission for Ca) atomic spectrometry (FAAS/FAES) with the use of a spectrometer (SpectraAA 240 FS, Varian). Previously, serum samples were wet mineralized. Reaction mixtures consisting of $1 \mathrm{~g}$ of serum, $5 \mathrm{~cm}^{3}$ of $65 \%$ nitric acid $(\mathrm{V})$ and $1 \mathrm{~cm}^{3}$ of hydrogen peroxide, after incubation overnight at room temperature, were mineralized in a closed microwave system MARS 5 over $10 \mathrm{~min}$ at $180^{\circ} \mathrm{C}$ and $180 \mathrm{psi}$ and then transferred quantitatively into volumetric flasks of $10 \mathrm{~cm}^{3}$ using redistilled water [60-62]. The concentrations of $\mathrm{Ca}$ and $\mathrm{Mg}$ were expressed in $\mathrm{mg} / \mathrm{dL}$, while the concentrations of $\mathrm{Zn}, \mathrm{Fe}$ and $\mathrm{Cu}$ were expressed in $\mu \mathrm{g} / \mathrm{dL}$. The concentrations of mineral elements in MS were classified using reference values for pregnant women in the 3rd trimester (Table 2) [58].

\subsection{Determination of $3^{\prime}$ Nitrotyrosine in Cord Blood Serum of Newborns as an Oxidative Stress Marker}

Umbilical cord blood samples were collected during caesarean section. Blood samples after clotting were centrifuged for $15 \mathrm{~min}$ at $2000 \mathrm{rpm}$. Serum samples were removed and stored at $-80^{\circ} \mathrm{C}$ until the analysis [59]. The concentration of $3^{\prime} \mathrm{NT}$ in umbilical cord serum (UCS) was measured in duplicate with enzyme-linked immunosorbent assay (General Nitrotyrosine, 3NT ELISA Kit, EIAab, Wuhan, China). The absorption was measured with an Epoch plate reader (Bio-Tek Instruments, Winooski, VT, USA). Concentrations of $3^{\prime} \mathrm{NT}$ were expressed as $\mathrm{pg} / \mathrm{mL}$.

\subsection{Statistical Analysis}

Statistical analysis was performed with STATISTICA software, version 10.0. Spearman's correlation was applied to estimate the association between continuous variables (no conditions for $t$ test). The Mann-Whitney test was used to compare the rank between two groups of independent variables while the Kruskal-Wallis test was used to compare the variance between more than two groups of independent variables. For all analyses, $p \leq 0.05$ was considered significant [63]. In the Results section, the size of subgroups (N), median values $(\mathrm{Me})$ and interquartile range (IQR) are presented.

\subsection{Ethical Approval}

The study was approved by the Bioethics Committee at the Medical University of Wroclaw, Poland (record number KB-158/2016). All pregnant women were informed about the aims of the study and gave their written informed consent.

\section{Results}

Figure 2 presents median concentrations of $3^{\prime} \mathrm{NT}$ in the UCS in newborns in relation to sex. No statistically significant difference in $3^{\prime} \mathrm{NT}$ in UCS was demonstrated between female and male newborns $(p=0.963)$. 


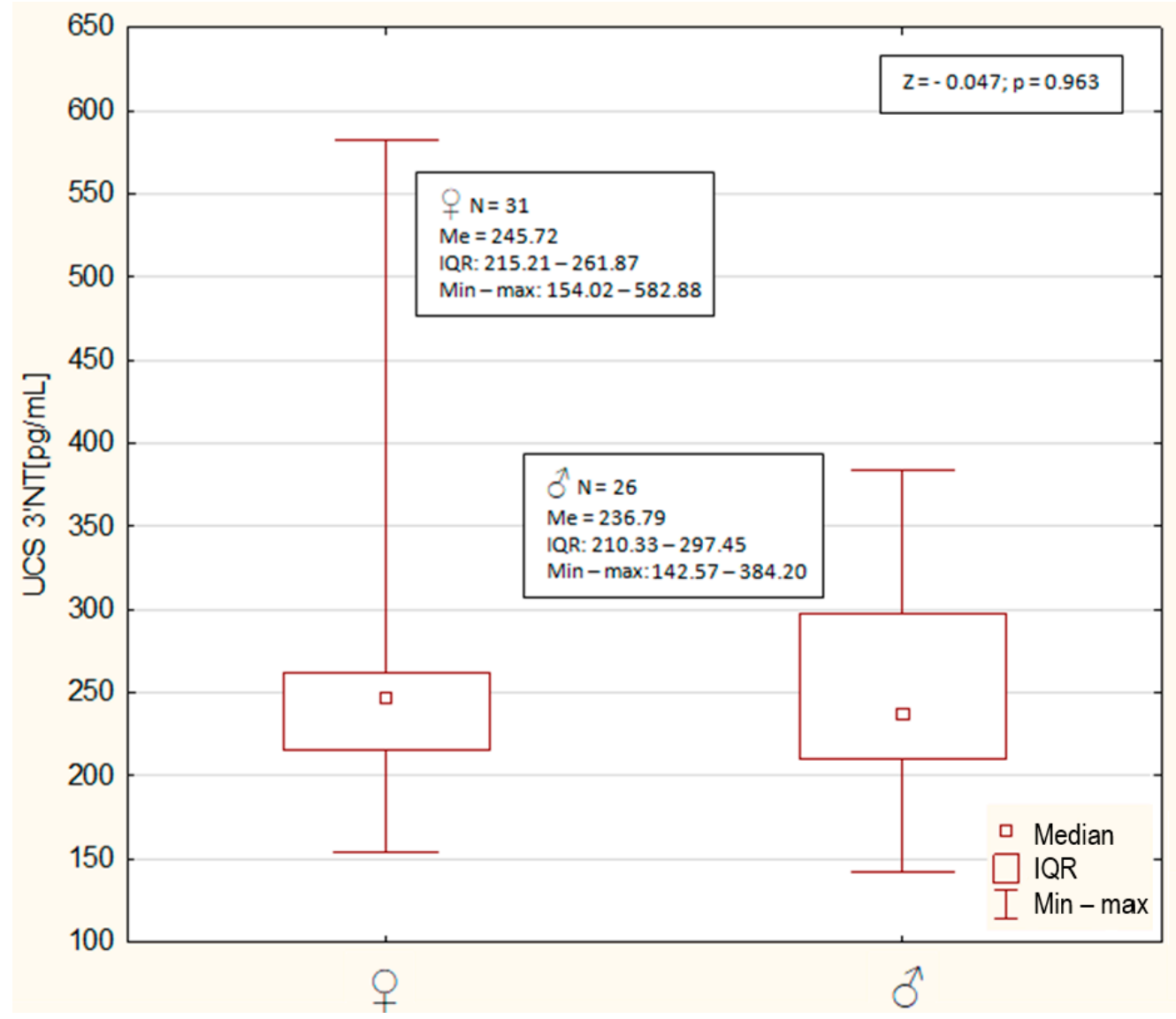

Figure 2. Median concentrations (Me), interquartile range (IQR) and the range (min-max) of 3'nitrotyrosine in cord blood

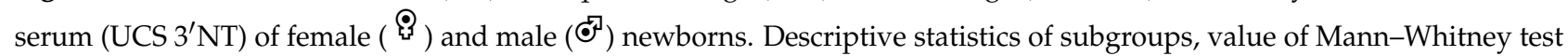
$(\mathrm{Z})$ and $p$ value are presented in frames.

Results of Spearman's correlation between the concentrations of $\mathrm{Mg}, \mathrm{Ca}, \mathrm{Zn}, \mathrm{Fe}$ and $\mathrm{Cu}$ in the MS and the concentration of $3^{\prime} \mathrm{NT}$ in the UCS of all newborns (regardless of sex), female newborns and male newborns are presented in Table 3. A statistically significant negative correlation was observed between the concentration of $\mathrm{Cu}$ in the MS and the concentration of $3^{\prime} \mathrm{NT}$ in the UCS, but only in male newborns (rho $=-0.509, p=0.008$ ). Simultaneously, the concentration of $3^{\prime} \mathrm{NT}$ in the UCS of male newborns was positively correlated at the edge of statistical significance ( $r h o=0.392, p=0.053)$ with the concentration of Fe in the MS. No significant relationship of examined mineral elements with OS in female newborns and all newborns was found.

Table 3. Spearman's correlation between the concentration of selected mineral elements in maternal blood serum and the concentration of 3'nitrotyrosine in cord blood serum of all newborns, female newborns and male newborns.

\begin{tabular}{|c|c|c|c|c|c|c|}
\hline \multirow[t]{2}{*}{$\begin{array}{c}\text { Examined } \\
\text { Mineral Elements }\end{array}$} & \multicolumn{2}{|c|}{$\begin{array}{c}\text { UCS } 3^{\prime} \mathrm{NT}(\mathrm{pg} / \mathrm{mL}) \\
(\mathrm{N}=57)\end{array}$} & \multicolumn{2}{|c|}{$\begin{array}{c}\mathrm{UCS} 3^{\prime} \mathrm{NT}(\mathrm{pg} / \mathrm{mL}) \\
(\mathrm{N}=31)\end{array}$} & \multicolumn{2}{|c|}{$\begin{array}{c}\mathrm{UCS} 3^{\prime} \mathrm{NT}(\mathrm{pg} / \mathrm{mL}) \sigma^{\circ} \\
(\mathrm{N}=26)\end{array}$} \\
\hline & rho & $p$ & rho & $p$ & rho & $p$ \\
\hline MS Mg (mg/dL) & 0.045 & 0.740 & -0.183 & 0.325 & 0.252 & 0.214 \\
\hline MS Ca (mg/dL) & 0.108 & 0.423 & 0.036 & 0.848 & 0.123 & 0.550 \\
\hline MS Zn $(\mu \mathrm{g} / \mathrm{dL})$ & -0.042 & 0.768 & -0.343 & 0.074 & 0.141 & 0.500 \\
\hline MS Fe $(\mu \mathrm{g} / \mathrm{dL})$ & 0.233 & 0.093 & -0.054 & 0.786 & 0.392 & $\underline{0.053}$ \\
\hline MS Cu $(\mu \mathrm{g} / \mathrm{dL})$ & -0.179 & 0.184 & 0.246 & 0.182 & -0.509 & $0.008^{*}$ \\
\hline
\end{tabular}

MS—maternal serum, UCS—umbilical cord serum, Mg—magnesium, Ca—calcium, Zn—zinc, Fe-iron, Cu-copper, 3'NT—3'nitrotyrosine,

8 -female newborns, $\mathbb{F}_{-}$-male newborns, ${ }^{*}$ statistically significant $(p \leq 0.05)$, _ at the edge of statistical significance. 
The concentration of $3^{\prime} \mathrm{NT}$ in the UCS in relation to the concentration of selected mineral elements in the MS (insufficient, optimal and excessive) and the results of MannWhitney tests between subgroups are presented in Table 4 . No significant differences were demonstrated in the concentration of $3^{\prime} \mathrm{NT}$ in UCS between newborns whose mothers had insufficient, excessive or optimal concentrations of $\mathrm{Mg}, \mathrm{Fe}$ and $\mathrm{Cu}$ in the MS. As all the examined pregnant women were characterized by an excessive level of $\mathrm{Ca}$ and the vast majority of them had insufficient levels of $\mathrm{Zn}$, division into quartiles of these mineral elements was applied. The concentration of $3^{\prime} \mathrm{NT}$ in the UCS in relation to the concentration of $\mathrm{Ca}$ and $\mathrm{Zn}$ in the MS $\left(\mathrm{Q}_{1}, \mathrm{Q}_{2}, \mathrm{Q}_{3}, \mathrm{Q}_{4}\right)$ and the results of Kruskal-Wallis tests between subgroups are presented in Table 5 . No significant differences in $3^{\prime}$ NT in the UCS between the analysed subgroups were observed.

Table 4. The concentration of $3^{\prime}$ nitrotyrosine in umbilical cord serum in relation to the concentration of selected mineral elements in maternal serum (insufficient, optimal and excessive).

\begin{tabular}{|c|c|c|c|c|c|c|c|c|c|c|c|}
\hline \multirow{3}{*}{$\begin{array}{c}\text { Examined } \\
\text { Mineral Elements }\end{array}$} & \multicolumn{9}{|c|}{ UCS $3^{\prime}$ NT $[\mathrm{pg} / \mathrm{mL}]$} & \multirow{3}{*}{ MW-Z } & \multirow{3}{*}{$p$} \\
\hline & \multicolumn{3}{|c|}{ Insufficient } & \multicolumn{3}{|c|}{ Optimal } & \multicolumn{3}{|c|}{ Excessive } & & \\
\hline & $\mathbf{N}$ & Me & IQR & $\mathbf{N}$ & Me & IQR & $\mathbf{N}$ & Me & IQR & & \\
\hline MS Mg [mg/dL] & 9 & 244.05 & $227.23-261.70$ & 48 & 245.06 & $214.88-275.00$ & 0 & - & - & -0.077 & 0.939 \\
\hline MS Ca [mg/dL] & 0 & - & - & 0 & - & - & 57 & 245.49 & 215.21-272.42 & - & - \\
\hline MS Fe $[\mu \mathrm{g} / \mathrm{dL}]$ & 1 & - & - & 22 & 244.86 & $216.07-261.70$ & 34 & 246.00 & $213.97-304.90$ & -0.741 & 0.459 \\
\hline MS Zn [ $\mu \mathrm{g} / \mathrm{dL}]$ & 55 & 245.37 & 213.97-269.76 & 2 & - & - & 0 & - & - & - & - \\
\hline MS Cu $[\mu \mathrm{g} / \mathrm{dL}]$ & 38 & 239.87 & $214.55-274.40$ & 18 & 249.34 & $218.63-266.20$ & 1 & - & - & -0.202 & 0.841 \\
\hline
\end{tabular}

MS—maternal serum, UCS—umbilical cord serum, Mg—magnesium, Ca—calcium, Zn—zinc, Fe—iron, Cu—copper, 3'NT—3'nitrotyrosine, $\mathrm{Me}$ - median, IQR — interquartile range, MW-Z—result of Mann-Whitney test.

Table 5. The concentration of 3'nitrotyrosine in umbilical cord serum in relation to the concentration of calcium and zinc in maternal serum divided into quartiles.

\begin{tabular}{|c|c|c|c|c|c|c|c|c|c|c|c|c|c|c|}
\hline \multirow{3}{*}{$\begin{array}{l}\text { Examined } \\
\text { Mineral } \\
\text { Elements }\end{array}$} & \multicolumn{12}{|c|}{ UCS $3^{\prime} \mathrm{NT}[\mathrm{pg} / \mathrm{mL}]$} & \multirow{3}{*}{ KW-H } & \multirow{3}{*}{$p$} \\
\hline & \multicolumn{3}{|c|}{$\mathrm{Q}_{1}$} & \multicolumn{3}{|c|}{$\mathrm{Q}_{2}$} & \multicolumn{3}{|c|}{$\mathrm{Q}_{3}$} & \multicolumn{3}{|c|}{$\mathrm{Q}_{4}$} & & \\
\hline & $\mathbf{N}$ & $\mathrm{Me}$ & IQR & $\mathbf{N}$ & Me & IQR & $\mathbf{N}$ & Me & IQR & $\mathbf{N}$ & Me & IQR & & \\
\hline $\begin{array}{l}\text { MS Ca } \\
{[\mathrm{mg} / \mathrm{dL}]}\end{array}$ & 15 & 234.04 & 215.21-258.73 & 13 & 253.90 & $237.96-272.42$ & 13 & 243.85 & $202.62-261.70$ & 16 & 247.33 & 221.49-310.09 & 1.610 & 0.657 \\
\hline $\begin{array}{l}\text { MS Zn } \\
{[\mu \mathrm{g} / \mathrm{dL}]}\end{array}$ & 14 & 252.01 & 232.01-310.09 & 16 & 229.28 & 202.62-272.42 & 13 & 245.49 & $210.33-266.20$ & 14 & 249.81 & $237.96-310.56$ & 1.735 & 0.629 \\
\hline
\end{tabular}

MS—-maternal serum, UCS—umbilical cord serum, Ca—calcium, Zn—zinc, $3^{\prime} \mathrm{NT}-3^{\prime}$ nitrotyrosine, Me—median, IQR- interquartile range, $\mathrm{KW}-\mathrm{H}-$ result of Kruskal-Wallis test.

The scatterplots of the concentration of $3^{\prime} \mathrm{NT}$ in the UCS in relation to the concentration of Fe in MS were analysed for all newborns (regardless of sex), female newborns and male newborns. On the scatterplots concerning all newborns and male newborns (in contrast to the scatterplot concerning female newborns), two clearly separated subgroups were observed with the cut-offs for the concentration of Fe in the MS of $\leq 300$ and $>400 \mu \mathrm{g} / \mathrm{dL}$ (no cases for $\mathrm{MS} \mathrm{Fe}>300$ and $\leq 400 \mu \mathrm{g} / \mathrm{dL}$ ). In the form of a boxplot, the median concentrations of $3^{\prime} \mathrm{NT}$ in the UCS in all newborns (regardless of sex) in relation to the concentration of Fe in the MS $\leq 300$ and $>400 \mu \mathrm{g} / \mathrm{dL}$ and the results of Mann-Whithey test between subgroups are presented on the Figure $3 \mathrm{~A}$. A significantly lower concentration of $3^{\prime} \mathrm{NT}$ in the UCS $(p<0.001)$ was demonstrated in newborns whose mothers were characterized by serum Fe concentration up to $300 \mu \mathrm{g} / \mathrm{dL}$ compared to those of mothers with serum Fe concentration higher than $400 \mu \mathrm{g} / \mathrm{dL}$.

In the form of a boxplot, the median concentrations of $3^{\prime} \mathrm{NT}$ in the UCS of male newborns in relation to the concentration of Fe in the MS of $\leq 300$ and $>400 \mu \mathrm{g} / \mathrm{dL}$ and the results of Mann-Whitney test between subgroups are presented on the Figure 3B. A significantly lower concentration of $3^{\prime} \mathrm{NT}$ in the UCS $(p=0.004)$ was demonstrated in male newborns whose mothers were characterized by a serum Fe concentration up to $300 \mu \mathrm{g} / \mathrm{dL}$ compared to those of mothers with a serum Fe concentration higher than $400 \mu \mathrm{g} / \mathrm{dL}$. 


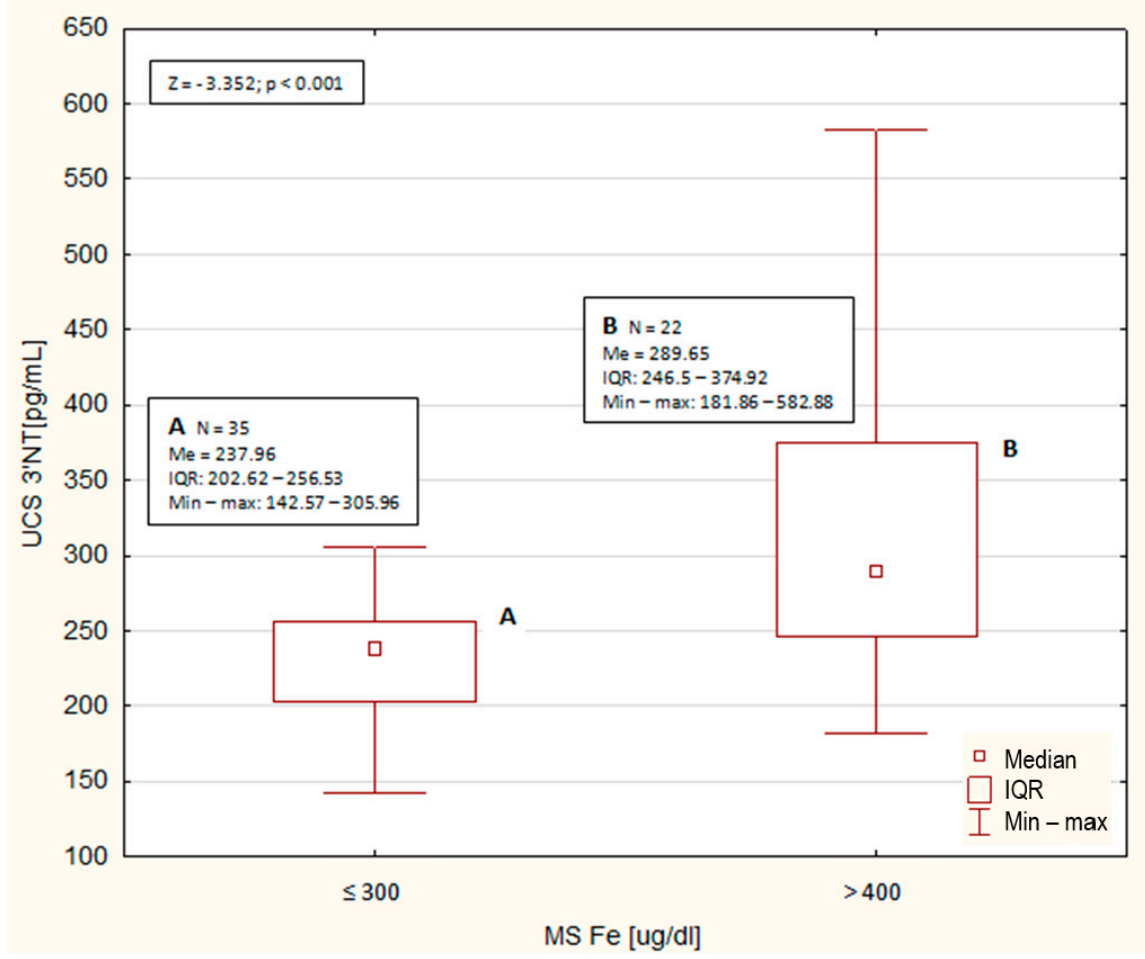

(A)

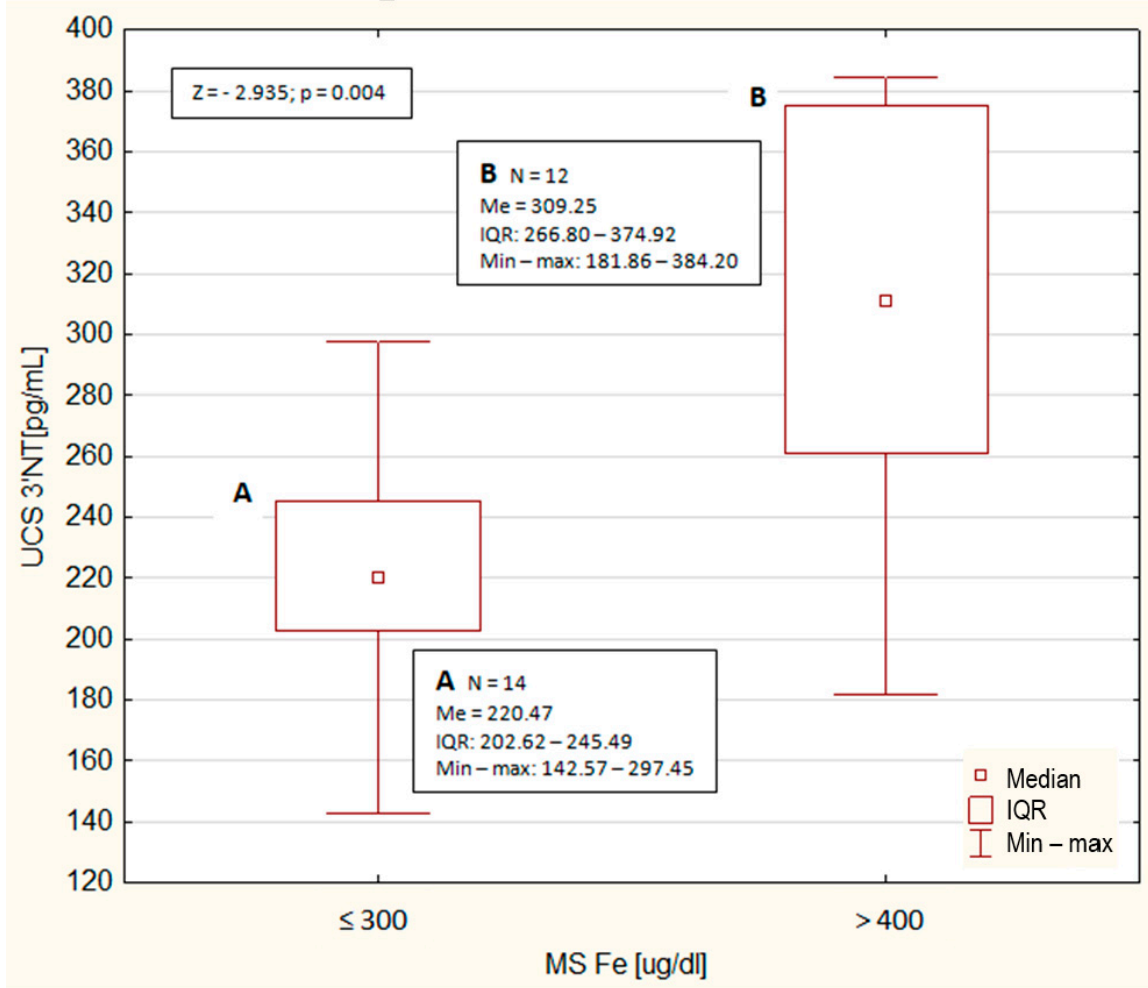

(B)

Figure 3. (A) Median concentrations (Me), interquartile range (IQR) and the range (Min-max) of $3^{\prime}$ nitrotyrosine in cord blood serum (UCS $3^{\prime} \mathrm{NT}$ ) of all newborns (regardless of sex) in relation to the concentration of Fe in the MS of $\leq 300$ and $>400 \mu \mathrm{g} / \mathrm{dL}$. Descriptive statistics of subgroups (A and B), value of Mann-Whitney test (Z) and $p$ value are presented in frames. (B) Median concentrations (Me), interquartile range (IQR) and the range (Min-max) of 3 'nitrotyrosine in cord blood serum (UCS $3^{\prime} \mathrm{NT}$ ) of male newborns in relation to the concentration of Fe in the MS of $\leq 300$ and $>400 \mu \mathrm{g} / \mathrm{dL}$. Descriptive statistics of subgroups (A and B), value of Mann-Whitney test (Z) and $p$ value are presented in frames. 


\section{Discussion}

Results of this study showed a positive correlation between the level of OS in newborns and the concentration of Fe in MS. Moreover, a very high Fe concentration in the blood serum of pregnant women, exceeding $400 \mu \mathrm{g} / \mathrm{dL}$, seemed to increase the level of OS in newborns. Importantly, a significant relationship was observed, especially in male neonates.

Although, according to the author's knowledge, there are no studies available in the literature strictly regarding the relationship between MS Fe concentration (or another marker of body Fe saturation) and the level of OS in newborns, some relationships regarding this issue have been clarified.

Both Fe deficiency and excess during pregnancy are presented as unfavourable factors for foetal development, and the relationship is defined as U-shaped [64,65]. However, an excessive concentration of $\mathrm{Fe}$ acts as one of the key pro-oxidative factors by driving the Fenton reaction and the production of highly reactive hydroxyl radicals [13]. It has been shown that Fe supersaturation in the prenatal period may increase the risk of miscarriage, prematurity, low birth weight, and being small for gestational age (SGA) [64,66], as well as disturb the development of the foetal brain $[67,68]$, and OS was demonstrated as one of the probable mechanisms leading to these abnormalities [64,69].

It is also known from a few reports that there is a relationship between the state of Fe saturation and the level of OS in pregnant women. Mannaerts et al. (2018) showed a positive correlation between the concentration of ferritin and superoxide anion in the blood of pregnant women [70]. In turn, Aly et al. (2016) found a positive correlation between the concentration of Fe and malondialdehyde, as well as the concentration of ferritin and total antioxidant capacity (TAC), in the blood of pregnant women [71]. These results prove the pro-oxidative properties of $\mathrm{Fe}$, the increase in concentration which is associated with an increase in the production of free radicals and lipid peroxidation, and the mobilization of antioxidant mechanisms.

Much more research has been conducted on the effects of dietary Fe supplementation of pregnant women on the level of OS in their body. The results, however, are polarized, depending on the initial state of Fe saturation. In pregnant women not suffering from $\mathrm{Fe}$ deficiency anaemia (IDA), prophylactic Fe supplementation clearly induced OS [72,73] and limited the antioxidant capacity of the organism [73-75]. The pro-oxidative effect probably resulted from the oversaturation of the body with free $\mathrm{Fe}$, the concentration of which exceeded the sequestration capacity of Fe-binding proteins, thus leading to the intensification of the Fenton and Haber-Weiss reactions and the production of ROS/RNS damaging biomolecules [76]. In turn, the use of dietary Fe supplementation in pregnant women with IDA had a beneficial antioxidant effect, with a significant decrease in the concentration of OS markers and an increase in the activity of antioxidant mechanisms [71,77]. Considering that Fe deficiency anaemia itself is a state of OS associated with an increased concentration of OS markers in the blood and a weakened activity of antioxidant mechanisms [71,78], equalization of Fe saturation to the optimal level, presented by pregnant women without IDA [71], seems to be a likely cause of lowering the level of OS after Fe supplementation in pregnant women with IDA.

Negative effects of prophylactic Fe supplementation in pregnant women without IDA have also been observed in their newborn babies, who are significantly more often born with SGA [79] and with low birth weight (LBW) [80]. Moreover, birth weight and gestational age at birth were significantly lower in newborns of mothers supplementing Fe in higher doses compared to those who consumed less Fe [80].

Contrary to the current $\mathrm{WHO}$ recommendations regarding dietary Fe supplementation in pregnant women at a dose of 30-60 mg daily throughout pregnancy, regardless of the state of Fe saturation in the body [81], the results presented in the literature on the effects of Fe supplementation in pregnant women demonstrated that it should not be used in women without IDA [82]. It is emphasized that the health consequences of supplementation strictly depend on the initial state of Fe saturation in the bodies of pregnant women $[64,83]$. 
While supplementation is beneficial in women with anaemia, such an intervention may be detrimental in women who are well-nourished with Fe.

The results of studies carried out in various research centres have therefore shown that prenatal Fe supersaturation promotes OS in the bodies of pregnant women $[70,71]$ and disturbs the normal growth and development of the foetus [64,66-68], which was also reflected in the results of studies on Fe supplementation in pregnant women without IDA $[72-75,79,80]$. The present study, in turn, demonstrated that the excessive concentration of $\mathrm{Fe}$ in the blood of pregnant women, exceeding $400 \mu \mathrm{g} / \mathrm{dL}$, contributes to an increased level of OS in neonates, as well as a generally positive correlation between these variables.

The results of this study also showed a negative correlation between the level of OS in male newborns and the concentration of $\mathrm{Cu}$ in MS. There are no reports in the available literature that would allow a direct comparison of the obtained results.

It is known, however, that $\mathrm{Cu}$, as a transition metal, can exhibit both antioxidant properties through the induction of $\mathrm{Cu}$-dependent antioxidant enzymes (including $\mathrm{Cu}$ Zn SOD, Se GPx and CAT) and pro-oxidative properties by participating in free radical reactions. Therefore, an insufficient $\mathrm{Cu}$ nutrition status results in the impairment of antioxidant mechanisms $[50,52,53]$, while its excessive concentration promotes the production of ROS/RNS [48]. Hence, the relationship between the nutritional status of $\mathrm{Cu}$ and the level of OS is U-shaped.

It has been established that both inadequate and excessive concentrations of $\mathrm{Cu}$ in the blood of pregnant women are associated with adverse health effects for the mother and the child. In pregnant women with pre-eclampsia, the pathogenesis of which is clearly associated with an elevated level of OS [84], an increased [85] or reduced [86-88] Cu concentration in maternal blood was observed. A lower blood $\mathrm{Cu}$ concentration was also found by Biswas et al. (2016) in women with gestational hypertension compared to that in healthy pregnant women [89]. Neural tube defects, including foetal anencephaly, also appear to be associated with both maternal $\mathrm{Cu}$ deficiency [90,91] and its excess [92], and OS was suggested as one of the probable mechanisms [55,93,94]. Moreover, Wilson et al. (2018) showed that pregnant women with higher blood Cu levels (3rd tertile) had a significantly higher risk of gestational complications (pre-eclampsia, gestational diabetes, premature birth and/or SGA) compared to pregnant women whose $\mathrm{Cu}$ blood concentration was within the 1st and 2nd tertiles. The authors also found a positive correlation between the concentration of $\mathrm{Cu}$ and acute phase proteins (APPs) in the blood of pregnant women, and they considered that to be evidence of the pro-inflammatory and pro-oxidative mechanisms of the development of these complications [95]. The case study presented by Walker et al. (2011) suggests that excessive $\mathrm{Cu}$ concentration in the blood of pregnant women can lead to autism and cardiological problems in their offspring in childhood [96]. Similar problems are diagnosed in Wilson's disease associated with disturbed metabolism of $\mathrm{Cu}$ leading to the supersaturation of the body with this mineral element [97]. However, in the study by Walker et al. (2011) [96], there is no mention of a potential mechanism linking an excessive concentration of $\mathrm{Cu}$ in the blood of pregnant women to autism and cardiological problems in the offspring, aetiopathogenesis of cardiovascular dysfunctions as well as autism spectrum disorders (ASD) [6,98]. Moreover, Shen et al. (2015) observed a decreased $\mathrm{Cu}$ concentration in the blood of pregnant women whose children were born with intrauterine growth restriction (IUGR) [99]. Additionally, Pathak and Kapil (2004) summarized the literature, recognizing the deficiency of trace elements, including $\mathrm{Cu}$, as one of the causes of infertility, miscarriages, gestational hypertension, placental abruption, premature rupture of membranes (PROM), congenital malformations and low birth weight (LBW) [100]. Li et al. (2018) also showed that both newborns with low (1st tertile) and high (3rd tertile) concentrations of $\mathrm{Cu}$ in the UCS had a significantly increased risk of being born prematurely or late, respectively [101]. Other researchers demonstrated a similar positive correlation between the concentration of $\mathrm{Cu}$ in the umbilical cord blood and foetal age [102-104]. 
The results presented in the discussion confirm the U-shaped relationship between the concentration of $\mathrm{Cu}$ in the blood of pregnant women and the health effects related to OS, representing the left $[86-91,99-101]$ or the right $[85,92,95,96,101]$ arm of the curve. Taking into account that the results obtained in the present study concerned a group of women characterized mostly by insufficient $\mathrm{Cu}$ concentrations $(66.7 \%)$, with a median value of 78.02 (IQR-44.00-123.20) $\mu \mathrm{g} / \mathrm{dL}$, the demonstrated correlation seems to support the U-shaped nature of the curve of the discussed relationship, representing its left arm, and suggesting the concentration of $3^{\prime} \mathrm{NT}$ in umbilical cord blood may decrease as the concentration of $\mathrm{Cu}$ in maternal blood approached the optimal values.

In the author's own research, the nutritional status of pregnant women seems to modify the level of OS mainly in male newborns. It would confirm the conclusions presented by Lavoie and Tremblay (2018) after reviewing studies from 1990 to 2017 on the relationship between the level of OS and the sex of newborns. They found that the blood concentrations of OS markers were higher and the antioxidant capacity was lower in male neonates compared to those in female neonates [105]. In animal models, it was also unequivocally demonstrated that the susceptibility of the foetus to OS was sex-dependent. Increased antioxidant activity in response to placental insufficiency [106], prenatal betamethasone exposure [107] and malnutrition [108] were observed only in female neonates. This proves more efficient compensation mechanisms in the female sex and greater sensitivity to unfavourable conditions of the intrauterine environment and OS in the male sex. Potentially protective effects may include female sex hormones (oestrogens) [109-111], as well as a higher adaptive capacity of the female placenta [112], and more adaptable strategies of the development of female foetuses [113] to the stressful conditions of the intrauterine environment.

It is worth noting that the present study, according to our best knowledge, examined for the first time the OS in newborns in relation to the status of mineral nutrition in pregnancy. Our study, however, has several limitations, including moderately large study group (below minimum sample size [114,115]), a cross-sectional nature instead of a multiple model, and no adjustment for potential confounding factors (e.g., obesity, older maternal age), therefore further extensive studies on this issue are needed.

\section{Conclusions}

In conclusion, a significant relationship between the nutritional status with mineral elements in pregnant women and the level of OS in their newborn children has been demonstrated. A significantly excessive concentration of Fe in the blood serum of pregnant women, exceeding $400 \mu \mathrm{g} / \mathrm{dL}$, seemed to promote OS in newborns. Moreover, results of the study seem to support a U-shaped relationship between the level of neonatal OS and the mother's blood $\mathrm{Cu}$ concentration, suggesting the concentration of $3^{\prime} \mathrm{NT}$ in umbilical cord blood may decrease as the concentration of $\mathrm{Cu}$ in maternal blood approached the optimal values. Interestingly, the impact of the nutritional status of pregnant women on the level of OS was observed mainly in male newborns.

The results of the study showed the need to develop strategies to optimize the nutritional status of pregnant women. Implementation of these strategies could contribute to reducing the risk of pre- and neonatal OS and its adverse health effects in the offspring, including disorders classified as "oxygen radical disease in neonatology", as well as cardiometabolic and immune diseases in later life resulting from foetal programming.

However, the presented conclusions must be confirmed in further studies. It would be greatly recommended to conduct them longitudinally throughout pregnancy, on a larger population of pregnant women and their newborn children, exceeding the minimum sample size. Moreover, in further studies, more markers of OS should be included, e.g., the concentrations of the products of protein, lipid and DNA oxidation, the levels of antioxidants, the activity of antioxidant enzymes, and various oxidant and antioxidant indicators. Additionally, as there are many potential confounding factors that may influence OS in newborns, such as maternal age, diet, physical activity, maternal BMI, gestational 
weight gain and others mentioned in the introduction [7-10], it would be meaningful to include them into a fully adjusted multivariate model.

Further extensive research on this issue, conducted on a sufficiently large study group and adjusted for potential confounding factors will guarantee the scientific credibility of the results, enable the generalization of the results from the sample to the entire population and enable the application of the results to create nutritional recommendations for pregnant women aimed at reducing the levels of OS in newborns. The results obtained in this study should be considered as an important turn signal for future research.

Author Contributions: Conceptualization: K.R. and M.B.; methodology: K.R., K.Ł., M.S. and Ł.B.; validation: K.R., K.Ł., M.S. and Ł.B.; formal analysis: K.R. and M.B.; investigation: K.R.; data curation: K.R.; writing—original draft preparation: K.R.; writing-review and editing: M.B., K.R., K.Ł., M.S. and Ł.B.; visualization: K.R.; supervision: M.B.; project administration: K.R. and M.B.; and funding acquisition: K.R. and M.B. All authors have read and agreed to the published version of the manuscript.

Funding: This research was funded by the Faculty of Biotechnology and Food Science, Wroclaw University of Environmental and Life Sciences [under Grant nr B030/0015/16] and Wroclaw Centre of Biotechnology, programme The Leading National Research Centre (KNOW) for years 2014-2018 [under Grant nr P/2016/4].

Institutional Review Board Statement: The study was conducted according to the guidelines of the Declaration of Helsinki, and approved 24.03.2016 by the Bioethics Committee at the Medical University of Wroclaw, Poland (KB-158/2016).

Informed Consent Statement: Participating pregnant women signed informed consent for themselves and their newborn children.

Data Availability Statement: Data are available on reasonable request from the corresponding author.

Acknowledgments: The authors wish to thank Wojciech Witkiewicz, Director of Provincial Specialist Hospital in Wroclaw, Research and Development Centre and Janusz Malinowski, the head of the Obstetrics and Gynaecology Ward, for their permission to carry out the research in the hospital and ward. Many thanks also to our midwives-Barbara Smolińska and Elżbieta Ciesielska for collecting maternal blood samples and their kindness.

Conflicts of Interest: The authors declare no conflict of interest.

\section{References}

1. Grosicka-Maciag, E. Biological consequences of oxidative stress induced by pesticides. Postepy Hig. Med. Dosw. 2011, 65, 357-366. [CrossRef] [PubMed]

2. Ambrożewicz, E.; Bielawska, K. Protein carbonylation-reasons, effects and determination. Postepy Biochem. 2016, 62, 495-505. [PubMed]

3. Szwed, A.; Miłowska, K. The role of proteins in neurodegenerative disease. Postepy Hig. Med. Dosw. (Online) 2012, 66, 187-195. [CrossRef]

4. Pham-Huy, L.A.; He, H.; Pham-Huy, C. Free radicals, antioxidants in disease and health. Int. J. Biomed. Sci. 2008, 4, 89-96. [PubMed]

5. Souza, J.M.; Peluffo, G.; Radi, R. Protein tyrosine nitration-functional alteration or just a biomarker? Free Radic. Biol Med. 2008, 45, 357-366. [CrossRef] [PubMed]

6. Rodríguez-Rodríguez, P.; Ramiro-Cortijo, D.; Reyes-Hernández, C.G.; López de Pablo, A.L.; González, M.C.; Arribas, S.M. Implication of Oxidative Stress in Fetal Programming of Cardiovascular Disease. Front. Physiol. 2018, 9, 602. [CrossRef] [PubMed]

7. Macpherson, A.J.; de Agüero, M.G.; Ganal-Vonarburg, S.C. How nutrition and the maternal microbiota shape the neonatal immune system. Nat. Rev. Immunol. 2017, 17, 508-517. [CrossRef]

8. Waterland, R.A. Epigenetic mechanisms affecting regulation of energy balance: Many questions, few answers. Annu. Rev. Nutr. 2014, 34, 337-355. [CrossRef]

9. Ramakrishnan, U.; Grant, F.; Goldenberg, T.; Zongrone, A.; Martorell, R. Effect of women's nutrition before and during early pregnancy on maternal and infant outcomes: A systematic review. Paediatr. Perinat. Epidemiol. 2012, 26 (Suppl. 1), $285-301$. [CrossRef]

10. Gitto, E.; Pellegrino, S.; D'Arrigo, S.; Barberi, I.; Reiter, R.J. Oxidative stress in resuscitation and in ventilation of newborns. Eur. Respir. J. 2009, 34, 1461-1469. [CrossRef] [PubMed] 
11. Rizzo, A.; Roscino, M.T.; Binetti, F.; Sciorsci, R.L. Roles of reactive oxygen species in female reproduction. Reprod. Domest. Anim. 2012, 47, 344-352. [CrossRef] [PubMed]

12. Brook, B.; Harbeson, D.; Ben-Othman, R.; Viemann, D.; Kollmann, T.R. Newborn susceptibility to infection vs. disease depends on complex in vivo interactions of host and pathogen. Semin. Immunopathol. 2017, 39, 615-625. [CrossRef] [PubMed]

13. Saugstad, O.D. Oxidative stress in the newborn-A 30-year perspective. Biol. Neonate 2005, 88, 228-236. [CrossRef] [PubMed]

14. Saugstad, O.D. The oxygen radical disease in neonatology. Indian J. Pediatr. 1989, 56, 585-593. [CrossRef]

15. Ozsurekci, Y.; Aykac, K. Oxidative Stress Related Diseases in Newborns. Oxid. Med. Cell. Longev. 2016. [CrossRef]

16. Mukhopadhyay, B.; Gongopadhyay, A.N.; Rani, A.; Gavel, R.; Mishra, S.P. Free radicals and antioxidants status in neonates with congenital malformation. J. Indian Assoc. Pediatr. Surg. 2015, 20, 179-183.

17. Hracsko, Z.; Orvos, H.; Novak, Z.; Pal, A.; Varga, I.S. Evaluation of oxidative stress markers in neonates with intra-uterine growth retardation. Redox Rep. 2008, 13, 11-16. [CrossRef]

18. Banks, B.A.; Ischiropoulos, H.; McClelland, M.; Ballard, P.L.; Ballard, R.A. Plasma 3-nitrotyrosine is elevated in premature infants who develop bronchopulmonary dysplasia. Pediatrics 1998, 101, 870-874. [CrossRef]

19. Aydemir, C.; Dilli, D.; Uras, N.; Ulu, H.O.; Oguz, S.S.; Erdeve, O.; Dilmen, U. Total oxidant status and oxidative stress are increased in infants with necrotizing enterocolitis. J. Pediatric Surg. 2011, 46, 2096-2100. [CrossRef]

20. Negi, R.; Pande, D.; Karki, K.; Kumar, A.; Khanna, R.S.; Khanna, H.D. A novel approach to study oxidative stress in neonatal respiratory distress syndrome. BBA Clin. 2015, 3, 65-69. [CrossRef] [PubMed]

21. Perrone, S.; Tataranno, M.L.; Santacroce, A.; Bracciali, C.; Riccitelli, M.; Alagna, M.G.; Longini, M.; Belvisi, E.; Bazzini, F.; Buonocore, G. Fetal programming, maternal nutrition, and oxidative stress hypothesis. J. Pediatric Biochem. 2016, 6, 96-102.

22. Fernandez-Twinn, D.S.; Constância, M.; Ozanne, S.E. Intergenerational epigenetic inheritance in models of developmental programming of adult disease. Semin. Cell Dev. Biol. 2015, 43, 85-95. [CrossRef] [PubMed]

23. Maffeis, C.; Morandi, A. Effect of Maternal Obesity on Foetal Growth and Metabolic Health of the Offspring. Obes. Facts 2017, 10, 112-117. [CrossRef] [PubMed]

24. Desai, M.; Jellyman, J.K.; Ross, M.G. Epigenomics, gestational programming and risk of metabolic syndrome. Int. J. Obes. 2015, 39, 633-641. [CrossRef]

25. Giussani, D.A.; Camm, E.J.; Niu, Y.; Richter, H.G.; Blanco, C.E.; Gottschalk, R.; Blake, E.Z.; Horder, K.A.; Thakor, A.S.; Hansell, J.A.; et al. Developmental programming of cardiovascular dysfunction by prenatal hypoxia and oxidative stress. PLoS ONE 2012, 7, e31017. [CrossRef]

26. Christian, P.; Stewart, C.P. Maternal micronutrient deficiency, fetal development, and the risk of chronic disease. J. Nutr. 2010, 140, 437-445. [CrossRef]

27. Prentice, S. They Are What You Eat: Can Nutritional Factors during Gestation and Early Infancy Modulate the Neonatal Immune Response? Front. Immunol. 2017, 8, 1641. [CrossRef]

28. Amarasekera, M.; Prescott, S.L.; Palmer, D.J. Nutrition in early life, immune-programming and allergies: The role of epigenetics. Asian Pac. J. Allergy Immunol. 2013, 31, 175-182.

29. Jennewein, M.F.; Abu-Raya, B.; Jiang, Y.; Alter, G.; Marchant, A. Transfer of maternal immunity and programming of the newborn immune system. Semin. Immunopathol. 2017, 39, 605-613. [CrossRef]

30. Marques, A.H.; O'Connor, T.G.; Roth, C.; Susser, E.; Bjørke-Monsen, A.L. The influence of maternal prenatal and early childhood nutrition and maternal prenatal stress on offspring immune system development and neurodevelopmental disorders. Front. Neurosci. 2013, 7, 120. [CrossRef]

31. Palmer, A.C. Nutritionally mediated programming of the developing immune system. Adv. Nutr. 2011, 2, 377-395. [CrossRef] [PubMed]

32. Jones, K.D.; Berkley, J.A.; Warner, J.O. Perinatal nutrition and immunity to infection. Pediatric Allergy Immunol. 2010, 21, 564-576. [CrossRef]

33. Gernand, A.D.; Schulze, K.J.; Stewart, C.P.; West, K.P., Jr.; Christian, P. Micronutrient deficiencies in pregnancy worldwide: Health effects and prevention. Nat. Rev. Endocrinol. 2016, 12, 274-289. [CrossRef] [PubMed]

34. Baker, H.; DeAngelis, B.; Holland, B.; Gittens-Williams, L.; Barrett, T., Jr. Vitamin profile of 563 gravidas during trimesters of pregnancy. J. Am. Coll. Nutr. 2002, 21, 33-37. [CrossRef]

35. Darnton-Hill, I.; Mkparu, U.C. Micronutrients in pregnancy in low- and middle-income countries. Nutrients 2015, 7, 1744-1768. [CrossRef] [PubMed]

36. Black, R.E.; Victora, C.G.; Walker, S.P.; Bhutta, Z.A.; Christian, P.; de Onis, M.; Ezzati, M.; Grantham-McGregor, S.; Katz, J.; Martorell, R.; et al. Maternal and child undernutrition and overweight in low-income and middle-income countries. Lancet 2013, 382, 427-451. [CrossRef]

37. Torheim, L.E.; Ferguson, E.L.; Penrose, K.; Arimond, M. Women in resource-poor settings are at risk of inadequate intakes of multiple micronutrients. J. Nutr. 2010, 140, 2051s-2058s. [CrossRef] [PubMed]

38. Parisi, F.; Laoreti, A.; Cetin, I. Multiple micronutrient needs in pregnancy in industrialized countries. Ann. Nutr. Metab. 2014, 65, 13-21. [CrossRef]

39. Livock, M.; Anderson, P.J.; Lewis, S.; Bowden, S.; Muggli, E.; Halliday, J. Maternal micronutrient consumption periconceptionally and during pregnancy: A prospective cohort study. Public Health Nutr. 2017, 20, 294-304. [CrossRef] 
40. Hatzopoulou, K.; Filis, V.; Grammatikopoulou, M.G.; Kotzamanidis, C.; Tsigga, M. Greek pregnant women demonstrate inadequate micronutrient intake despite supplement use. J. Diet. Suppl. 2014, 11, 155-165. [CrossRef] [PubMed]

41. Cordain, L.; Eaton, S.B.; Sebastian, A.; Mann, N.; Lindeberg, S.; Watkins, B.A.; O'Keefe, J.H.; Brand-Miller, J. Origins and evolution of the Western diet: Health implications for the 21st century. Am. J. Clin. Nutr. 2005, 81, 341-354. [CrossRef] [PubMed]

42. Giorgi, C.; Marchi, S.; Pinton, P. The machineries, regulation and cellular functions of mitochondrial calcium. Nat. Rev. Mol. Cell Biol. 2018, 19, 713-730. [CrossRef] [PubMed]

43. Attar, T. A mini-review on importance and role of trace elements in the human organism. Coll. Res. Libr. 2020, 3, 117-130.

44. Chasapis, C.T.; Loutsidou, A.C.; Spiliopoulou, C.A.; Stefanidou, M.E. Zinc and human health: An update. Arch. Toxicol. 2012, 86, 521-534. [CrossRef] [PubMed]

45. Nemeth, E.; Tuttle, M.S.; Powelson, J.; Vaughn, M.B.; Donovan, A.; Ward, D.M.; Ganz, T.; Kaplan, J. Hepcidin regulates cellular iron efflux by binding to ferroportin and inducing its internalization. Science 2004, 306, 2090-2093. [CrossRef]

46. Pierzchała, O.; Ogórek, M.; Bednarz, A.; Lenartowicz, M. Structure and function of proteins belonging to the CTR family-membrane transporters of the monovalent metal ions. Postępy Biol. Komórki 2015, 42, 351-374.

47. Lee, S.R. Critical role of zinc as either an antioxidant or a prooxidant in cellular systems. Oxid. Med. Cell. Longev. 2018, 2018, 9156285. [CrossRef]

48. Serdar, Z.; Gur, E.; Develioglu, O. Serum iron and copper status and oxidative stress in severe and mild preeclampsia. Cell Biochem. Funct. 2006, 24, 209-215. [CrossRef]

49. Cassat, J.E.; Skaar, E.P. Iron in infection and immunity. Cell Host Microbe 2013, 13, 509-519. [CrossRef]

50. Uriu-Adams, J.Y.; Keen, C.L. Copper, oxidative stress, and human health. Mol. Asp. Med. 2005, 26, 268-298. [CrossRef]

51. Nairz, M.; Haschka, D.; Demetz, E.; Weiss, G. Iron at the interface of immunity and infection. Front. Pharmacol. $2014,5,152$. [CrossRef]

52. Uriu-Adams, J.Y.; Scherr, R.E.; Lanoue, L.; Keen, C.L. Influence of copper on early development: Prenatal and postnatal considerations. Biofactors 2010, 36, 136-152. [CrossRef]

53. Hawk, S.N.; Lanoue, L.; Keen, C.L.; Kwik-Uribe, C.L.; Rucker, R.B.; Uriu-Adams, J.Y. Copper-deficient rat embryos are characterized by low superoxide dismutase activity and elevated superoxide anions. Biol. Reprod. 2003, 68, 896-903. [CrossRef] [PubMed]

54. Brilla, L.R. Magnesium influence on stress and immune function in exercise. J. Sports Med. Doping Stud. 2012, 2. [CrossRef]

55. Rayssiguier, Y.; Gueux, E.; Bussiere, L.; Mazur, A. Copper deficiency increases the susceptibility of lipoproteins and tissues to peroxidation in rats. J. Nutr. 1993, 123, 1343-1348.

56. De Clercq, K.; Vriens, J. Establishing life is a calcium-dependent TRiP: Transient receptor potential channels in reproduction. Biochim. Biophys. Acta Mol. Cell Res. 2018, 1865, 1815-1829. [CrossRef] [PubMed]

57. Khayat, S.; Fanaei, H.; Ghanbarzehi, A. Minerals in Pregnancy and Lactation: A Review Article. JCDR 2017, 11. [CrossRef]

58. Abbassi-Ghanavati, M.; Greer, L.G.; Cunningham, F.G. Pregnancy and laboratory studies: A reference table for clinicians. Obstet. Gynecol. 2009, 114, 1326-1331. [CrossRef]

59. Tuck, M.K.; Chan, D.W.; Chia, D.; Godwin, A.K.; Grizzle, W.E.; Krueger, K.E.; Rom, W.; Sanda, M.; Sorbara, L.; Stass, S.; et al. Standard operating procedures for serum and plasma collection: Early detection research network consensus statement: Standard operating procedure integration working group. J. Proteome. Res. 2009, 8, 113-117. [CrossRef]

60. European Committee for Standardization, EN 15505. Foodstuffs. Determination of Trace Elements. Determination of Sodium and Magnesium by Flame Atomic Absorption Spectrometry (AAS) after Microwave Digestion; CEN: Brussels, Belgium, 2009.

61. European Committee for Standardization, EN 14082. Foodstuffs. Determination of Trace Elements. Determination of Lead, Cadmium, Zinc, Copper and Iron by Atomic Absorption Spectrometry (AAS) after Dry Ashing; CEN: Brussels, Belgium, 2003.

62. Food and Nutrition Institute, PB-06/AAS. Determination of Calcium in Milk and Dairy Products by Flame Atomic Emission Spectrometry (EAS); Food and Nutrition Institute: Warsaw, Poland, 2013.

63. Stanisz, A. The Accessible Course of Statistics with Use the STATISTICA PL for Medicine Examples; Basic Statistics; StatSoft Polska: Kraków, Poland, 2006; Volume 1.

64. Dewey, K.G.; Oaks, B.M. U-shaped curve for risk associated with maternal hemoglobin, iron status, or iron supplementation. Am. J. Clin. Nutr. 2017, 106 (Suppl. 6), 1694s-1702s. [CrossRef] [PubMed]

65. Rao, R.; Georgieff, M.K. Iron in fetal and neonatal nutrition. Semin. Fetal. Neonatal Med. 2007, 12, 54-63. [CrossRef]

66. Breymann, C. Iron Deficiency Anemia in Pregnancy. Semin. Hematol. 2015, 52, 339-347. [CrossRef] [PubMed]

67. Wessling-Resnick, M. Excess iron: Considerations related to development and early growth. Am. J. Clin. Nutr. 2017, 106 (Suppl. 6), 1600s-1605s. [CrossRef]

68. Khwaja, O.; Volpe, J.J. Pathogenesis of cerebral white matter injury of prematurity. Arch. Dis. Child. Fetal Neonatal Ed. 2008, 93, F153-F161. [CrossRef]

69. Adibhatla, R.M.; Hatcher, J.F. Lipid oxidation and peroxidation in CNS health and disease: From molecular mechanisms to therapeutic opportunities. Antioxid. Redox Signal. 2010, 12, 125-169. [CrossRef]

70. Mannaerts, D.; Faes, E.; Cos, P.; Briedé, J.J.; Gyselaers, W.; Cornette, J.; Gorbanev, Y.; Bogaerts, A.; Spaanderman, M.; Van Craenenbroeck, E.; et al. Oxidative stress in healthy pregnancy and preeclampsia is linked to chronic inflammation, iron status and vascular function. PLoS ONE 2018, 13, e0202919. [CrossRef] 
71. Aly, S.S.; Fayed, H.M.; Ahmed, S.S.; Abdella, A.H.; Tamam, A.-A.E.; Mohmmed, N.A. Effects of oral iron (ferrous versus ferric) supplementation on oxidative stress and antioxidant status in pregnant women with iron deficiency: Controlled trial. Egypt J. Haematol 2016, 41, 31-41.

72. Viteri, F.E.; Casanueva, E.; Tolentino, M.C.; Díaz-Francés, J.; Erazo, A.B. Antenatal iron supplements consumed daily produce oxidative stress in contrast to weekly supplementation in Mexican non-anemic women. Reprod. Toxicol. 2012, 34, 125-132. [CrossRef] [PubMed]

73. Lachili, B.; Hininger, I.; Faure, H.; Arnaud, J.; Richard, M.J.; Favier, A.; Roussel, A.M. Increased lipid peroxidation in pregnant women after iron and vitamin C supplementation. Biol. Trace Elem. Res. 2001, 83, 103-110. [CrossRef]

74. Lymperaki, E.; Tsikopoulos, A.; Makedou, K.; Paliogianni, E.; Kiriazi, L.; Charisi, C.; Vagdatli, E. Impact of iron and folic acid supplementation on oxidative stress during pregnancy. J. Obstet. Gynaecol. 2015, 35, 803-806. [CrossRef] [PubMed]

75. Anetor, J.I.; Ajose, O.A.; Adeleke, F.N.; Olaniyan-Taylor, G.O.; Fasola, F.A. Depressed antioxidant status in pregnant women on iron supplements: Pathologic and clinical correlates. Biol Trace Elem. Res. 2010, 136, 157-170. [CrossRef] [PubMed]

76. Zhuang, T.; Han, H.; Yang, Z. Iron, oxidative stress and gestational diabetes. Nutrients 2014, 6, 3968-3980. [CrossRef]

77. Ma, A.G.; Schouten, E.G.; Sun, Y.Y.; Yang, F.; Han, X.X.; Zhang, F.Z.; Jiang, D.C.; Kok, F.J. Supplementation of iron alone and combined with vitamins improves haematological status, erythrocyte membrane fluidity and oxidative stress in anaemic pregnant women. Br. J. Nutr. 2010, 104, 1655-1661. [PubMed]

78. Khalid, S.; Shaikh, F.; Imran-Ul-Haq, H.S. Oxidative stress associated with altered activity of glutathione peroxidase and superoxide dismutase enzymes with IDA during pregnancy. Pak. J. Pharm. Sci. 2019, 32, 75-79. [PubMed]

79. Ziaei, S.; Norrozi, M.; Faghihzadeh, S.; Jafarbegloo, E. A randomised placebo-controlled trial to determine the effect of iron supplementation on pregnancy outcome in pregnant women with haemoglobin > or = $13.2 \mathrm{~g} / \mathrm{dL}$. BJOG 2007, 114, 684-688. [CrossRef] [PubMed]

80. Shastri, L.; Mishra, P.E.; Dwarkanath, P.; Thomas, T.; Duggan, C.; Bosch, R.; McDonald, C.M.; Thomas, A.; Kurpad, A.V. Association of oral iron supplementation with birth outcomes in non-anaemic South Indian pregnant women. Eur. J. Clin. Nutr. 2015, 69, 609-613. [CrossRef] [PubMed]

81. World Health Organization. Guideline: Daily Iron and Folic Acid Supplementation in Pregnant Women; WHO: Geneva, Switzerland, 2012.

82. Martínez García, R.M. Supplements in pregnancy: The latest recommendations. Nutr. Hosp. 2016, 33 (Suppl 4), 336.

83. Mwangi, M.N.; Prentice, A.M.; Verhoef, H. Safety and benefits of antenatal oral iron supplementation in low-income countries: A review. Br. J. Haematol. 2017, 177, 884-895. [CrossRef]

84. Mistry, H.D.; Gill, C.A.; Kurlak, L.O.; Seed, P.T.; Hesketh, J.E.; Méplan, C.; Schomburg, L.; Chappell, L.C.; Morgan, L.; Poston, L. Association between maternal micronutrient status, oxidative stress, and common genetic variants in antioxidant enzymes at 15 weeks' gestation in nulliparous women who subsequently develop preeclampsia. Free Radic. Biol. Med. 2015, 78, 147-155. [CrossRef]

85. Basu, A.; Yu, J.Y.; Jenkins, A.J.; Nankervis, A.J.; Hanssen, K.F.; Henriksen, T.; Lorentzen, B.; Garg, S.K.; Menard, M.K.; Hammad, S.M.; et al. Trace elements as predictors of preeclampsia in type 1 diabetic pregnancy. Nutr. Res. 2015, 35, 421-430. [CrossRef]

86. Al-Jameil, N.; Tabassum, H.; Al-Mayouf, H.; Aljohar, H.I.; Alenzi, N.D.; Hijazy, S.M.; Khan, F.A. Analysis of serum trace elementscopper, manganese and zinc in preeclamptic pregnant women by inductively coupled plasma optical emission spectrometry: A prospective case controlled study in Riyadh, Saudi Arabia. Int. J. Clin. Exp. Pathol. 2014, 7, 1900-1910.

87. Sarwar, M.S.; Ahmed, S.; Ullah, M.S.; Kabir, H.; Rahman, G.K.; Hasnat, A.; Islam, M.S. Comparative study of serum zinc, copper, manganese, and iron in preeclamptic pregnant women. Biol. Trace Elem. Res. 2013, 154, 14-20. [CrossRef]

88. Kumru, S.; Aydin, S.; Simsek, M.; Sahin, K.; Yaman, M.; Ay, G. Comparison of serum copper, zinc, calcium, and magnesium levels in preeclamptic and healthy pregnant women. Biol. Trace Elem. Res. 2003, 94, 105-112. [CrossRef]

89. Biswas, S.; Roy, A.; Biswas, S. Comparative study of copper, zinc, ferritin, calcium and magnesium levels in pregnancy induced hypertension and normotensive primigravida mothers. Int. J. Res. Med. Sci. 2016, 4, 1879-1883. [CrossRef]

90. Morton, M.S.; Elwood, P.C.; Abernethy, M. Trace elements in water and congenital malformations of the central nervous system in South Wales. Br. J. Prev. Soc. Med. 1976, 30, 36-39. [CrossRef]

91. Buamah, P.K.; Russell, M.; Milford-Ward, A.; Taylor, P.; Roberts, D.F. Serum copper concentration significantly less in abnormal pregnancies. Clin. Chem. 1984, 30, 1676-1677. [CrossRef]

92. Cengiz, B.; Söylemez, F.; Oztürk, E.; Cavdar, A.O. Serum zinc, selenium, copper, and lead levels in women with second-trimester induced abortion resulting from neural tube defects: A preliminary study. Biol. Trace Elem. Res. 2004, 97, 225-235. [CrossRef]

93. Olin, K.L.; Walter, R.M.; Keen, C.L. Copper deficiency affects selenoglutathione peroxidase and selenodeiodinase activities and antioxidant defense in weanling rats. Am. J. Clin. Nutr. 1994, 59, 654-658. [CrossRef]

94. Prohaska, J.R.; Wells, W.W. Copper deficiency in the developing rat brain: Evidence for abnormal mitochondria. J. Neurochem. 1975, 25, 221-228. [CrossRef] [PubMed]

95. Wilson, R.L.; Bianco-Miotto, T.; Leemaqz, S.Y.; Grzeskowiak, L.E.; Dekker, G.A.; Roberts, C.T. Early pregnancy maternal trace mineral status and the association with adverse pregnancy outcome in a cohort of Australian women. J. Trace Elem. Med. Biol. 2018, 46, 103-109. [CrossRef] [PubMed]

96. Walker, L.R.; Rattigan, M.; Canterino, J. A case of isolated elevated copper levels during pregnancy. J. Pregnancy 2011, 2011, 385767. [CrossRef] 
97. Roberts, E.A.; Schilsky, M.L. Diagnosis and treatment of Wilson disease: An update. Hepatology 2008, 47, 2089-2111. [CrossRef] [PubMed]

98. Carpita, B.; Muti, D.; Dell'Osso, L. Oxidative stress, maternal diabetes, and autism spectrum disorders. Oxid. Med. Cell Longev. 2018, 2018. [CrossRef]

99. Shen, P.J.; Gong, B.; Xu, F.Y.; Luo, Y. Four trace elements in pregnant women and their relationships with adverse pregnancy outcomes. Eur. Rev. Med. Pharmacol. Sci. 2015, 19, 4690-4697. [PubMed]

100. Pathak, P.; Kapil, U. Role of trace elements zinc, copper and magnesium during pregnancy and its outcome. Indian J. Pediatr. 2004, 71, 1003-1005. [CrossRef] [PubMed]

101. Li, Z.; Liang, C.; Huang, K.; Yan, S.; Tao, R.; Sheng, J.; Pan, W.; Xia, X.; Tao, Y.; Xiang, H.; et al. Umbilical Serum Copper Status and Neonatal Birth Outcomes: A Prospective Cohort Study. Biol. Trace Elem. Res. 2018, 183, 200-208. [CrossRef]

102. Wells, E.M.; Jarrett, J.M.; Lin, Y.H.; Caldwell, K.L.; Hibbeln, J.R.; Apelberg, B.J.; Herbstman, J.; Halden, R.U.; Witter, F.R.; Goldman, L.R. Body burdens of mercury, lead, selenium and copper among Baltimore newborns. Environ. Res. 2011, 111, 411-417. [CrossRef]

103. Galinier, A.; Périquet, B.; Lambert, W.; Garcia, J.; Assouline, C.; Rolland, M.; Thouvenot, J.P. Reference range for micronutrients and nutritional marker proteins in cord blood of neonates appropriated for gestational ages. Early Hum. Dev. 2005, 81, 583-593. [CrossRef]

104. Algerwie, M.H.; Khatri, P.C. Serum copper in newborns and their mothers. Indian J. Pediatrics 1998, 65, 899-903. [CrossRef] [PubMed]

105. Lavoie, J.C.; Tremblay, A. Sex-Specificity of Oxidative Stress in Newborns Leading to a Personalized Antioxidant Nutritive Strategy. Antioxidants 2018, 7, 49. [CrossRef] [PubMed]

106. Ojeda, N.B.; Royals, T.P.; Alexander, B.T. Sex differences in the enhanced responsiveness to acute angiotensin II in growthrestricted rats: Role of fasudil, a Rho kinase inhibitor. Am. J. Physiol. Renal Physiol. 2013, 304, F900-F907. [CrossRef] [PubMed]

107. Bi, J.; Contag, S.A.; Chen, K.; Su, Y.; Figueroa, J.P.; Chappell, M.C.; Rose, J.C. Sex-specific effect of antenatal betamethasone exposure on renal oxidative stress induced by angiotensins in adult sheep. Am. J. Physiol. Renal Physiol. 2014, 307, F1013-F1022. [CrossRef]

108. Rodríguez-Rodríguez, P.; de Pablo, A.L.; Condezo-Hoyos, L.; Martín-Cabrejas, M.A.; Aguilera, Y.; Ruiz-Hurtado, G.; GutierrezArzapalo, P.Y.; Ramiro-Cortijo, D.; Fernández-Alfonso, M.S.; González Mdel, C.; et al. Fetal undernutrition is associated with perinatal sex-dependent alterations in oxidative status. J. Nutr. Biochem. 2015, 26, 1650-1659. [CrossRef] [PubMed]

109. Zhu, C.; Wang, S.; Wang, B.; Du, F.; Hu, C.; Li, H.; Feng, Y.; Zhu, R.; Mo, M.; Cao, Y.; et al. 17ß-Estradiol up-regulates Nrf2 via $\mathrm{PI} 3 \mathrm{~K} / \mathrm{AKT}$ and estrogen receptor signaling pathways to suppress light-induced degeneration in rat retina. Neuroscience 2015, 304, 328-339. [CrossRef] [PubMed]

110. Alexander, B.T.; Henry Dasinger, J.; Intapad, S. Effect of low birth weight on women's health. Clin. Ther. 2014, 36, 1913-1923. [CrossRef] [PubMed]

111. Baek, I.J.; Jung, K.Y.; Yon, J.M.; Lee, S.R.; Lee, B.J.; Yun, Y.W.; Nam, S.Y. Phospholipid hydroperoxide glutathione peroxidase gene is regulated via an estrogen and estrogen receptor signaling in cultured mouse fetuses. Cell. Dev. Biol. Anim. 2011, 47, 535-540. [CrossRef]

112. Rosenfeld, C.S. Sex-Specific Placental Responses in Fetal Development. Endocrinology 2015, 156, 3422-3434. [CrossRef]

113. Eriksson, J.; Forsén, T.; Tuomilehto, J.; Osmond, C.; Barker, D. Fetal and childhood growth and hypertension in adult life. Hypertension 2000, 36, 790-794. [CrossRef]

114. Nayak, B.K. Understanding the relevance of sample size calculation. Indian J. Ophthalmol. 2010, 58, 469-470. [CrossRef]

115. Raosoft. Sample Size Calculator. Available online: http:/ / www.raosoft.com/samplesize.html (accessed on 22 April 2021). 